\title{
Filterisasi Hoax Dari Kemajuan Teknologi Komunikasi dan Informasi
}

\section{(Hoax Filtering Regarding the Advancement of Communication and Information Technology)}

\author{
Bahtiar \\ Program Studi Komunikasi dan Penyiaran Islam, Institut Agama Islam Negeri (IAIN) Langsa, Indonesia \\ email: mrlungs@yahoo.com
}

\begin{tabular}{ccc}
\hline First received: & Revised: & Final Accepted: \\
25 October 2020 & 28 November 2020 & 31 December 2020 \\
\hline
\end{tabular}

\begin{abstract}
The rapid advancement of technology nowadays makes human life easier. On the other hand, technological advances have actually led people to over-dependence and loss of self-confidence. This causes bumans negatively taking advantage of these technological advances to overthrow and dominate each other through slander and fake news. As the destructive effect of these technological advances is immense, the government as the controller of the technological progress should expurgate, especially, the distorted information that can tear the nation apart (hoax). This action can be taken by the government by utilizing the services of hackers to break into the system and build a cyber defense against fake information that is widely disseminated with the advances of communication and information technology. In addition, bumans, having the highest intelectual among other creatures in the world, must also build self-awareness. Therefore, technological advances which we have created do not become boomerangs that ultimately controls our life.
\end{abstract}

Keywords : Communication Technology; Filtering; Hoax; Information.

\section{ABSTRAK}

Kemajuan teknologi yang semakin pesat saat ini semakin memudahkan kehidupan manusia. Namun disisi lain kemajuan teknologi itu malah menggiring manusia pada ketergantungan secara berlebihan dan hilang kepercayaan diri. Sehingga manusia memanfaatkan kemajuan teknologi ini untuk saling menjatuhkan, menguasai lewat fitnah dan berita bohong. Besarnya pengaruh negative dari kemajuan teknologi tersebut, maka sudah seharusnya pemerintah sebagai pengendali dari kemajuan teknologi melakukan filterisasi. Terutama terhadap berbagai informasi menyimpang dan dapat merusak kebangsaan (boax). Langkah ini dapat dilakukan oleh pemerintah dengan memanfaatkan jasa para hacker untuk meretas dan membangun banteng pertahanan terhadap informasi hoax dari kemajuan teknologi komunikasi dan informasi tersebut. Selain itu, kita sebagai manusia, juga harus membangun kesadaran diri sebagai mahkluk paling tinggi diatas dunia. Sehingga kemajuan teknologi yang notabanenya dilahirkan oleh manusia, tidak menjadi boomerang yang akhirnya menguasai kehidupan manusia.

Kata kunci : Teknologi Komunikasi; Filterisasi; Hoaks; Informasi.

\section{PENDAHULUAN}

Kemajuan teknologi komunikasi dan informasi saat ini semakin tidak terbendung, hampir seluruh kehidupan manusia mulai mengalami ketergantungan terhadap perangkat teknologi komunikasi dan informasi. Bahkan kehidupan manusia mulai ditentukan oleh media itu sendiri yang notabanenya adalah hasil cipta karya manusi. Teknologi diciptakan untuk membantu dan memudahkan segala pekerjaan manusia dalam berbagai hal.

Seiring perkembangan keilmuan, kampuan manusia menciptakan berbagai teknologi untuk memudahkan pekerjaannya semakin mencapai level kesempurnaan. Marshall McLuhan (Griffin, 2003 : 341) yang membagikan sejarah peradaban manusia dalam empat periode, yaitu, a tribal age (era suku atau purba), literate age (era literal/huruf), a print age (era cetak), dan electronic 
age (era elektronik), mengakui bahwa perubahan peradaban dari empat periode itu dipengaruhi oleh penemuan berbagai kemajuan teknologi yang terus menuju pada level kesempurnaan. Menurutnya, transisi antar periode tadi tidaklah bersifat gradual atau evolusif, akan tetapi lebih disebabkan oleh penemuan teknologi komunikasi itu sendiri.

Saat ini kita melihat, pemanfaatan kemajuan teknologi komunikasi dan informasi bukan lagi sebatas kebutuhan pelengkap atau pendamping (secunder). Tapi telah menjadi kebutuhan pokok (primer) dan memunculkan ketergantungan tetap dalam kehidupan manusia. Bagaimana kita melihat orang-orang dengan berbagai usia pertumbuhan (generasi milenial) yang disibukkan dengan sarana teknologi komunikasi dan informasi untuk memenuhi berbagai kebutuhannya.

McLuhan telah mengemukakan dalam teori determinisme teknologi, bahwa perubahan pola kehidupan social manusia juga disebabkan oleh kamajuan teknologi yang merupakan hasil cipta karya manusia itu sendiri. Menurutnya, perubahan komunikasi dari teknologi itu telah membentyuk cara berfikir, berperilaku dan bergerak dari satu masa teknologi ke masa teknologi lainnya yang akhirnya memenuhi kehidupan manusia, (Griffin, 2003 : 343).

Determinisme teknologi komunikasi dan informasi merubah pola pikir manusia saat ini, ketergantungan terhadap teknologi telah membunuh rasa kepekaan manusia dan interaksi social. Manusia cendrung lebih membuka komunikasi dengan seseorang yang jauh dan tidak diketahui secara persis bentuk dan situasinya, daripada orang-orang sekitar yang dapat dijangkau secara komunikasi verbal dan nonverbal.

Ketergantungan pada teknologi telah membuat manusia lebih yakin dan percaya dengan responsive teknologi daripada responsive manusia secara nyata. Padahal responsive teknologi itu merupakan hasil desain manusia yang dilakukan untuk memudahkan melayani berbagai keluhan dan tanggapan yang disampaikan. Dimana tujuan desain tersebut untuk memudahkan manusia memberikan layanan konsultasi. Namun kemajuan teknologi akhirnya telah merubah perspektif manusia bahwa keberadaan teknologi lebih peka terhadap masalah yang dihadapi daripada manusia itu sendiri.

Bahkan ironinya lagi, dalam situasi tertentu, kemajuan teknologi komunikasi dan informasi tersebut juga telah dimanfaatkan untuk saling menjatuhkan satu sama lain. Kemudahan layanan sarana teknologi dalam menyebarkan informasi seperti handphone, computer, internet yang dilengkapi dengan berbagai aplikasi media social seperti facebook, twitter, whatsapp, instagram, patc, linked dan lainnya telah menggiring pola pikir manusia untuk saling menjatuhkan lewat pembentukan opini liar.

Kita tahu saat ini kemajuan teknologi komunikasi dan informasi sangat mudah dimanfaatkan untuk kejahatan, seperti transaksi terlarang (prostitusi online) sebagaimana yang sedang menghebohkan dunia artis tanah air saat ini. Juga untuk menyebarkan berbagai informasi yang sifatnya menghasut, provokatif, adu domba, bahkan sampai pada berita bohong dan fitnah atau HOAX.

Mudahnya keluar berbagai informasi dan berita yang mengandung salah satu unsur diatas tersebut, tidak terlepas dari perubahan pola pikir manusia yang diakibatkan oleh perkembangan teknologi komunikasi dan informasi. Sehingga membuat ketergantungan berbagai aktifitas pada teknologi yang akhirnya menggiring manusia pada kebebasan berekpresi dari sebuah situasi social. Dengan mudahnya manusia akanmelakukan berbagai upaya untuk saling menjatuhkan lewat informasi yang salah dan menyesatkan. Disisi lain manusia lainnya pun merespon informasi sesat tersebut yang masuk dalam genggamannya lewat salah satu perangkat teknologi.

Akhirnya, terjadi kegaduhan dan saling menuding serta saling membuka kelemahan yang berakhir pada dunia nyata serta bersinggungan dengan hukum. Banyak kita lihat kasus-kasus hukum di negeri ini yang berawal dari dunia maya dengan sarana teknologi dan berakhir dibalik jeruji besi. Atas kondisi inilah, maka perlu kiranya dilakukan filterisasi untuk menangkal berbagai berita hoax dari kemajuan teknologi komuniksi dan informasi saat ini. 


\section{METODE PENELITIAN}

Pada penelitian ini metode yang digunakan adalah pendekatan analisis kualitatif menggunakan pendekatan logika induktif. Peneliti menggunakan dua mcam teknik: Pertama, Studi Kepustakaan (Library Research), penelitian dilakukan dengan cara mengumpulkan semua data yang berasal dari literatur serta bahan bacaan yang relevan dengan penelitian ini. Hal tersebut dilakukan dengan cara membaca buku-buku, literatur, serta tulisan yang berkaitan dengan masalah yang dibahas. Kedua, Studi dokumen (Document Research), penelitian dilakukan dengan cara mengumpulkan data yang dianalisis dari dialog yang terdapat di dalam media sosial.

\section{HASIL PENELITIAN DAN PEMBAHASAN}

\section{Filterisasi HOAX Terhadap Teknologi}

Penyebaran berita bohong, fitnah dan opini liar selama ini telah menjadi trending topic dalam pemberitaan media di Indonesia. Apalagi saat ini Indonesia sedang menjalani tahun politik dalam rangkan Pemilihan Umum (Pemilu) legislative dan pemilihan presiden dan wakil presiden periode 2019 - 2024. Berbagai kelompok dan personal dengan tujuan dan kepentingan tertentu, memanfaatkan sarana teknologi dengan berbagai aplikasi media social untuk saling menyerang.

Kondisi ini semakin membahayakan dan mengancam stabilitas interaksi social masyarakat Indonesia yang diikat dengan nilai-nilai luhur pancasila. Sikap saling menghargai, saling melindungi dan saling tolong menolong dalam kebangsaan mulai tergerus oleh sikap egois yang dibangun atas dasar kemajuan teknologi. Karena kehadiran teknologi dianggap lebih mengerti dengan kondisi kehidupannya, sehingga mengikis rasa social (determinisme).

Untuk mengatasi semua permasalahan tersebut, maka perlu kiranya dilakukan filterisasi terhadap berbagai informasi yang beredar melalui media social. Baik secara teknologi yang menangkap langsung informasi yang salah lewat aplikasi sensor atau pemblokiran sebagaimana dilakukan oleh Kominfo. Maupun secara etika dengan kembali membangun kepekaan social masyarakat lewat penanaman kembali nilai-nilai luhur pancasila sebagai dasar kesatuan bangsa Indonesia.

Menyangkut filterisasi teknologi komunikasi, Ned Scoot dan Daniel Larimer selaku pendiri aplikasi media social berbasis blockchain dengan nama steemit.com, telah membentuk sebuah aplikasi penangkap informasi Hoax atau plagiat terhadap postingan pada media steemit tersebut. System filterisasi yang dilakukan steemit adalah menempatkan robot dengan nama @ cheetah dalam sistemnya. Sehingga setiap tulisan yang dinilai Hoax dan plagiat langsung ditangkap dan diberikan peringatan, sehingga pengguna steemit lainnya yang membaca tulisan tersebut tidak percaya lagi dengan informasi yang ada di dalamnya.

System seperti ini perlu dilakukan oleh pemerintah sebagai pemegang kekuasaan dalam mengendalikan transportasi elektronik. Supaya tidak ada informasi hoax, fitnah, penghinaan, atau pelecehan yang dapat mengancam kelangsungan Negara dan membunuh rasa kepekaan manusia beredar ditengah masyarakat.

Pemerintah juga perlu menggandeng para hacker untuk membangun pertahanan teknologi komunikasi dan informasi dari berbagai ancaman rasial baik dari dalam maupun dari luar. Karena keberadaan hacker dapat menjadi tembok untuk mengantisipasi penyebaran berbagai berita dan informasi bohong (hoax) ditengah masyarakat yang berpotensi memecahbelah bangsa. Sebab kemajuan teknologi yang diikuti dengan penghilangan batas dan jarak, akan terus mempengaruhi kehidupan social manusia untuk saling berkompetisi.

Dalam teori Utopia, (Griffin, 2003 : 350) manusia telah mengalami kemajuan yang sedemikian pesat. Modernitas manusia sudah tidak terelakkan lagi. Manusia dalam titik kemajuan modernitas, telah dihantar pada sebuah situasi yang sedemikian krusial. Modernitas telah membawa manusia pada kemajuan teknologi yang sedemikian pesat. Teknologi modern sudah menjadi alat perpanjangan tangan manusia. Manusia semakin dipermudah oleh sarana-sarana 
teknologi yang ada.

Karenanya perlu campur tangan pemerintah untuk mengantisipasi agar tidak terjadi kesalahan dalam pemanfaatan teknologi tersebut. Salah satu langkah yang harus dilakukan adalah memfilter setiap berita dan informasi yang beredar di masyarakat agar tidak melahirkan bibitbibit perpecahan.

\section{Memposisikan Manusia Diatas Teknologi}

Menurut Ismail Rajfi, manusia adalah makhluk hidup yang sangat sempurna, karena dilengkapi dengan semua pembawaan dan syarat - syarat yang diperlukan (Jalaluddin, 2003:12). Manusia mempunyai kelebihan yang luar biasa. Kelebihan itu adalah dikaruniainya akal. Dengan akal tersebut manusia dapat mengembangkan bakat dan potensi yang dimilikinya serta mampu mengatur dan mengelola alam semesta ini sebaik-baiknya.

Selain dilengkapi oleh akal, manusia juga dilengkapi dengan unsur lain yaitu qalbu (hati). Dengan qalbunya manusia dapat menjadikan dirinya sebagai makhluk bermoral, merasakan keindahan, kenikmatan beriman dan kehadiran ilahi secara spiritual (Jalaluddin, 2003:14).

Tingginya posisi manusia sebagai mahkluk dalam alam ini, tentunya memiliki kekuatan untuk mengendalikan alam termasuk teknologi didalamnya yang merupakan hasil cipta karya manusia itu sendiri. Selama ini kemajuan teknologi yang semakin memudahkan kerja-kerja manusia telah menyebabkan manusia lupa akan jati dirinya dan terperangkap dalam kemajuan teknologi sebagai budak. Manusia telah terperalat oleh kamajuan teknologi, yang seharusnya mengendalikan, namun terkendalikan.

Manusia telah menjadikan teknologi sebagai sandaran untuk berbagai keluhan dalam masalah. Bahkan manusia telah menjadikan teknologi sebagai andalan untuk melindungi diri dan akhirnya berada dibawah control teknologi. Kondisi ini semakin mengancam keberadaan manusia sebagai actor kehidupan menjadi budak teknologi.

Melirik posisi manusia yang sangat tinggi sebagai mahkluk, sebagaimana dikatakan oleh Jalaluddin, maka misi utama yang harus dilakukan oleh manusia itu sendiri dalam mengimbangi kemajuan teknologi adalah menyadari posisinya dan mengembalikan diri pada pemahaman manusia seutuhnya. Artinya manusia harus sadar bahwa kemajuan teknologi yang diciptakan untuk kemudahan kerja manusia. Bukan untuk mengendalikan kehidupan manusia yang menimbulkan ketergantungan tinggi. Akhirnya berada dibawah pengaruh teknologi dan bekerja dibawah arahannya.

Teori determinisme yang disampaikan oleh Marshall McLuhan, harus menjadi peringatan bagi kita sebagai manusia agar tidak terperangkap dalam kemajuan teknologi. Dimana Marshall McLuhan telah mengingatkan bahwa kemjauan teknologi telah mempengaruhi kehidupan manusia dalam berbagai hal. Bahkan kadang kala manusia bertindak diluar kesadarannya sebagai manusia, dan lenih mengikuti arahan teknologi.

\section{PENUTUP}

Kemajuan teknologi yang semakin pesat saat ini semakin memudahkan kehidupan manusia. Namun disisi lain kemajuan teknologi itu malah menggiring manusia pada ketergantungan secara berlebihan dan hilang kepercayaan diri. Sehingga manusia memanfaatkan kemajuan teknologi ini untuk saling menjatuhkan, menguasai lewat fitnah dan berita bohong.

Mudahnya operasional teknologi bagi manusia, semakin memudahkan manusia itu sendiri bertindak diluar nalar kemanusiaannya. Melalui berbagai aplikasi media social, manusia semakin berkompetisi untuk menampilkan dominasinya terhadap manusia lain. Berbagai hasutan, fitnah, berita bohong terus disebarkan yang akhirnya merusak interaksi social dunia nyata.

Besarnya pengaruh negative dari kemajuan teknologi tersebut, maka sudah seharusnya pemerintah sebagai pengendali dari kemajuan teknologi melakukan filterisasi. Terutama terhadap berbagai informasi menyimpang dan dapat merusak kebangsaan (hoax). Langkah ini dapat 
dilakukan oleh pemerintah dengan memanfaatkan jasa para hacker untuk meretas dan membangun banteng pertahanan terhadap informasi hoax dari kemajuan teknologi komunikasi dan informasi tersebut.

Selain itu, kita sebagai manusia, juga harus membangun kesadaran diri sebagai mahkluk paling tinggi diatas dunia. Sehingga kemajuan teknologi yang notabanenya dilahirkan oleh manusia, tidak menjadi boomerang yang akhirnya menguasai kehidupan manusia.

Kita sebagai mahkluk harus mampu mengendalikan sesuatu yang telah kita ciptakan, bukan sebaliknya kita dikendalikan oleh ciptaan (teknologi). Karl Marx percaya bahwa ilmu pengetahuan dan demokrasi adalah tangan kanan dan kiri dari apa yang ia sebut bergerak dari wilayah keharusan menuju wilayah kebebasan.

Dalam teori Utopia, techno-utopianisme mencerminkan keyakinan bahwa perubahan teknologi merevolusi urusan manusia, dan bahwa teknologi digital pada khususnya hanyalah pertanda sederhana akan meningkatkan kebebasan pribadi dengan membebaskan individu dari pelukan kaku birokrasi pemerintah besar.

\section{DAFTAR PUSTAKA}

Fisher, B. Aubrey (1978). Teori-TeoriKomunikasi, Bandung : Remaja Rosdakarya

Griffin, Emory A (2003). A First Look at Communication Theory, $5^{\text {th }}$ edition, New York : McGrawHill

Hanafi, Abdillah. Memahami Komunikasi Antar Manusia. Surabaya: Usaha Nasional, tt. Ishaq bin Ibrahim, Musnad Ishaq bin Ibrabim Rabuyah, Juz: 4 hal: 260

Hughes, James (2003). Rediscovering Utopia. Archived fromthe original on 2007

Jalaluddin (2013). Teologi Pendidikan. Jakarta, PT. Raja Grafindo Persada

John Hartley (2010). Communication, Cultural \& Media Studies, Jalasutra, Yogyakarta 